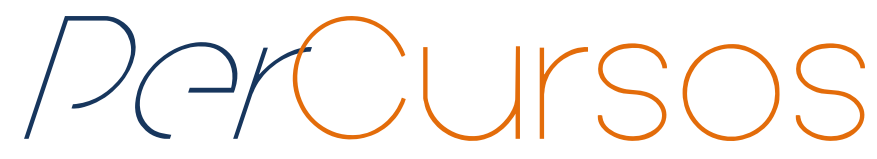

\title{
Migração e deserção na Polícia Militar de Minas Gerais ${ }^{1}$
}

\begin{abstract}
Resumo
A partir da década de 1980, o Brasil sofreu mudanças e passou de um país de imigrantes para um país de emigrantes. A emigração no Brasil, no que pese ter seu marco inicial nos anos de 1960, se ascendeu na década de $1980 \mathrm{com}$ ênfase na migração para os Estados Unidos da América (EUA). As primeiras emigrações em número expressivo ocorreram na cidade de Governador Valadares-MG. $O$ fluxo de informações e pessoas criou as primeiras redes que impulsionaram a emigração na região. $O$ fenômeno deixou marcas na cidade em vários segmentos, inclusive na segurança pública. A Polícia Militar de Minas Gerais, representada pela Oitava Região sediada em Governador Valadares, foi impactada de tal maneira que dos 286 policiais militares de todo o Estado que desertaram para migrar para os EUA, 138 pertenciam àquela região da Polícia, confirmando ser, esse, um território de cultura emigratória. Assim, o objetivo deste artigo é compreender os impactos da experiência migratória na percepção do território pelo policial militar que foi reintegrado após o retorno; o que foi demitido e o que, ainda, permanece no país de destino. Concluiu-se que os três grupos de militares, tiveram a percepção do território modificada após a experiência migratória e que, entre outros fatores, a ausência de uma norma que os punisse com a demissão, foi um estímulo preponderante na tomada da decisão de migrar.
\end{abstract}

Palavras-chave: Deserção; Migração; Percepção.
Luciovane Lopes

Mestre em Gestão Integrada do Território pela Universidade Vale do Rio Doce - UNIVALE. Brasil luciovane@gmail.com

\section{Sueli Siqueira}

Doutora em Ciências Humanas Sociologia e Política pela Universidade Federal de Minas Gerais - UFMG. Professora do Programa de Mestrado em Gestão Integrada do Território da Universidade Vale do Rio Doce -

UNIVALE.

Brasil

suelisq@hotmail.com

\footnotetext{
${ }^{1}$ Projeto de Pesquisa Migração e deserção na Polícia Militar de Minas Gerais, financiado pela Fundação de Amparo a Pesquisa do Estado de Minas Gerais - FAPEMIG.
} 


\title{
Migration and desertion in the military police of Minas
}

\section{Gerais}

\begin{abstract}
Starting in the first decade of 1980, the Brasil changed from a country of immigrants for a country of emigrants. The emigration in Brazil, in spite of having its initial milestone in the beginning of the 60s, will rise in the 80 s with emphasis in the migration to the USA. The first emigration in expressive numbers occurred first from the city of Governador Valadares-MG. The flow of information and people created the first networks and boosted emigration in the region. The phenomenon impacted the city in all its segments, including public safety. The Military Police of Minas Gerais, representedby the Eighth Region in Governador Valadares was also impacted so much as, that from the 286 police manpower that belonged to the whole state of Minas Gerais who have deserted the military to emigrate to the USA, 138 belonged to that Region, confirming that region be a territory of emigration culture. Thus, the main objective this research is to understand what was the impact of the migratory experience in the perception of the territory by the military police group that was reinstated after returning, the group that was dismissed and the one that still remains abroad. It is concluded that the three military groups, had their perception of the region modified after the migratory experience, and that, among other factors, the absence of a norm that punished with dismissal, was a highlight incentive in making a decision to migrate.
\end{abstract}

Keywords: Desertion; Migration; Perception.

\section{Para citar este artigo:}

LOPES, Luciovane; SIQUEIRA, Sueli. Migração e deserção na Polícia Militar de Minas Gerais. Revista PerCursos. Florianópolis, v. 16, n.32, p. 06 - 34, set./dez. 2015.

\section{DOI: $10.5965 / 1984724616322015006$}

http://dx.doi.org/10.5965/1984724616322015006 


\section{Introdução}

Segundo Siqueira (2009), A cidade de Governador Valadares, Estado de Minas Gerais, é marcada pelo intenso fluxo emigratório que ascendeu na região a partir da década de 1960, quando os primeiros Valadarenses aportaram no exterior, mais precisamente, nos Estados Unidos da América (EUA). Criou-se uma rede migratória que, conforme explica Fazito (2002), é constituída por agenciamento entre pessoas por meio de troca de experiências que buscam um único objetivo: o de migrar para um ponto específico.

Ao longo dos anos, esse fenômeno migratório impactou o município de Governador Valadares e seu entorno em suas várias dimensões, tornando-se uma alternativa viável de concretização de sonhos e projetos de melhorias das condições econômicas em virtude, principalmente, das redes sociais que se criaram fomentando o fluxo de informações acerca dos procedimentos para a partida e chegada do migrante nos EUA. Este artigo versa sobre um grupo específico que compôs esse fluxo: os militares que desertaram para emigrar.

No município de Governador Valadares está sediada a Oitava Região da Polícia Militar de Minas Gerais ( $8^{\mathrm{a}}$ RPM) que gerencia a Segurança Pública em 58 municípios circunvizinhos e foi diretamente afetada pelo fenômeno da migração. Dos 286 militares desertores em todo o Estado de Minas Gerais, 138 pertenciam àquela região (LOPES, 2011).

O militar ausente por mais de oito dias de sua Unidade, sem apresentar justificativa do seu não comparecimento, consuma o crime de deserção previsto no art. 187 do Código Penal Militar e passa a figurar no sistema de recursos humanos da Polícia Militar de Minas Gerais (PMMG) na condição de agregado por deserção. A Lei Estadual nº 5301/1969 que contém o Estatuto dos militares de Minas Gerais (EMEMG), em seu art. 125, define o agregado como o militar em situação temporária durante a qual fica afastado da atividade. Este afastamento dá-se em virtude de várias situações, uma delas é a deserção. (MINAS GERAIS, 1969)

É significativo o fato de $48 \%$ (quarenta e oito por cento) do total de desertores da 
PMMG, pertencerem a $8^{\mathrm{a}}$ RPM. Ressalta-se que desertavam com o objetivo de emigrar para os EUA. (MINAS GERAIS, 2013)

Até 17 de abril de 2007, os militares que cometiam o crime de deserção, ao retornarem para a atividade policial militar, por meio de apresentação ou captura e, após cumprir a pena criminal, detenção de seis meses a dois anos, prosseguiam na carreira militar gozando dos mesmos direitos e benefícios dos demais servidores. A partir de 17 de abril de 2007, entrou em vigor a Lei Complementar $n^{\circ} 95$ que passou a classificar o crime de deserção como atentatório à honra e ao decoro da classe militar, colocando a deserção como transgressão disciplinar de natureza grave, conduzindo o militar desertor ao Processo Administrativo Disciplinar (PAD), excluindo-o das fileiras da Polícia Militar. (MINAS GERAIS, 2007)

Apesar da norma que passou a demitir os militares que se encontravam na condição de desertores ter iniciado sua vigência em 17 de abril de 2007, vários militares permaneceram no país de destino e, atualmente, 39 (trinta e nove) deles ainda encontram-se nesta condição.

Dessa maneira, foram destacados neste estudo, 03 (três) grupos de militares que desertaram para migrar: os que retornaram e reingressaram na atividade policial militar; os que retornaram após a vigência da Lei Complementar $n^{\circ} 95$ e foram demitidos e os que ainda não retornaram.

Com base em estudo de natureza qualitativa utilizando dados primários obtidos por meio de entrevistas em profundidade e dados secundários colhidos no Sistema de Recursos Humanos da Polícia Militar (SIRH), buscou-se neste artigo compreender quais os impactos da experiência migratória na percepção do território pelo policial militar que foi reintegrado após o retorno; pelo que foi demitido e pelo que, ainda, permanece no país de destino. Escolheu-se a $8^{\circ}$ Região de Governador Valadares por apresentar um consistente campo para a pesquisa, tendo em vista a incidência do fenômeno da deserção nessa localidade.

Para responder à questão, serão analisados os fatores presentes no território que propiciaram a migração e o retorno (ou não retorno) dos militares desertores da Oitava 
Região da Polícia Militar ( $8^{\mathrm{a}}$ RPM), sede em Governador Valadares, que migraram para o exterior até o período de 2006. Foram realizadas quatorze entrevistas em profundidade, sendo cinco com militares que retornaram e foram readmitidos, cinco que foram demitidos e quatro que não retornaram (estes foram entrevistados via Skype). Para preservar os entrevistados, eles foram identificados por número, classe militar e situação quanto à migração (reintegrado, demitido e não retornado). A pesquisa de campo foi realizada entre os períodos de novembro de 2014 a janeiro de 2015.

Entende-se, aqui, como percepção do território a interação do sujeito da pesquisa com os elementos sociais e culturais desse território (origem e destino), a instituição militar e a sua própria condição de desertor. Também está inserida nesse conceito a visão do militar desertor a partir de sua decisão de migrar para outro país, seu agenciamento com o território de destino e sua readaptação no retorno ao país de origem, levando-se em consideração o processo de territorialização e desterritorialização.

\section{O impacto da experiência migratória na percepção do território.}

Conforme explica Ferreira (2004), perceber é adquirir conhecimento de alguma coisa pelos sentidos; compreender; dar-se conta de algo; atentar, reparar, notar. Nesse sentido, ao descrever o impacto da experiência migratória na percepção do território pelo policial militar que desertou para migrar para os EUA, buscar-se-á compreender o que mudou na percepção desse militar após a experiência migratória, ou seja, o que foi adquirido de conhecimento ou não em sua ida para os EUA: qual a visão de mundo, do território de origem e destino após essa aventura. O que modificou ou não em sua visão (percepção) da Polícia Militar e da visão de si mesmo como cidadão, como policial militar.Dentro dessa percepção, será utilizado o conceito de território trazido por Raffestin (1993) que é a transformação do espaço por meio das relações sociais de comunicação com utilização intencional do objeto pelo sujeito transformando-se o meio. Assim, pode se dizer que o termo "percepção do território" aqui utilizado é entendido como o conhecimento adquirido, percebido, notado pelo militar acerca dos espaços vividos e suas relações sociais, agenciamentos e conexões. 
Para compreender a percepção do território após a experiência migratória do militar que desertou, é necessário entender os fatores que estiveram presentes na decisão de migrar. Tomando por base os dizeres de Masseyet al (1993), De Hass (2010) e Skeldon (2012), vale reafirmar que nenhuma teoria é capaz de explicar sozinha o fenômeno migratório. Cada evento, cada movimento possui suas peculiaridades específicas, motivações diferenciadas e mesmo dentro de um único grupo, cada indivíduo será tomado por estímulos diferentes e em proporções diferentes. Assim, ao analisar os fatores que influenciaram os militares da $8^{\mathrm{a}}$ RPM na tomada da decisão de desertar para migrar para os EUA, é importante fazê-lo sem a pretensão de uma única resposta para os diversos casos.

Nos relatos dos entrevistados verifica-se que o fator econômico foi um forte estímulo na decisão de migrar. O sonho da casa própria, presente em treze casos, além da criação de uma reserva econômica, bem como o descontrole financeiro, demonstra o quanto a situação econômica do militar o influenciou na tomada de decisão. Como pode ser observado no relato do entrevistado 10, o principal motivo para esse migrante foi a necessidade de melhorar as condições financeira para sua família.

Eu já tinha três filhos, morava nos fundo da casa da minha mãe, lá num barracão meio assim que pertado né, e cinco pessoas conviver naquela situação ali, era difícil.E eu ainda tinha uns tratamento de saúde pra mim fazer né, tudo agregado dentro ali da renda mensal, aí ficou apertado pra mim né, aí ficou difícil. (Entrevistado 10, cabo retornado e reintegrado)

O fator econômico é tão incidente que em pesquisa feita por Lopes (2011) apenas 01 (um) pesquisado apresenta motivação não econômica. Dentro dessa motivação econômica, o sonho de comprar a casa própria aparece na quase totalidade dos militares. Para os militares que migraram, ter sua casa própria é não só uma questão de se sentir parte do território, mas também de se sentir seguro em relação à família e, ao mesmo tempo, dar segurança e estabilidade aos familiares.

Os entrevistados 5 e 2 demonstram a expectativa de realizar nos EUA seus sonhos de livrar-se das dívidas e adquirir a casa própria. Destaca-se, também nesses relatos a percepção da impossibilidade de realizar esses sonhos permanecendo em seu território. 
Porque do jeito que tava ia ser impossível eu um dia sonhar em ter uma casa própria, que eu só vou enrolando com dívida, e lá não. Lá eu vou zerar minhas despesa, minhas dívida, e ainda vou poder comprar uma casa. (Entrevistado 05, soldado retornado e demitido)

Então assim, a gente também tinha aquele sonho de ter uma vida melhor, uma casa, a casa sempre foi o sonho de toda pessoa, ter sua casa própria, eu não tinha casa própria, inclusive eu morava na casa dos meus pais, né quando eu casei e tal, então eu tinha aquele sonho de ter. (Entrevistado 02, cabo retornado e demitido)

Verifica-se que, apesar de o militar, naquela ocasião, ter uma estabilidade empregatícia e poder contar com um salário pago mês a mês, alguns optaram em migrar. Percebe-se, então, não se tratar apenas de uma dificuldade financeira causada pela situação econômica do país, uma vez que a grande parcela dos militares que desertaram para migrar, o fizeram nos anos de 2000, quando, segundo Pecequilo (2012), a economia brasileira apresentava sinais de melhora e crescimento. Dessa forma, entende-se que o fato de Governador Valadares ter constituído uma consistente rede de migração influenciou esse grupo de militares a abandonar o serviço policial militar rumo aos EUA, conforme relatos, de alguns dos envolvidos no processo, que se seguem.

Ah...a verdade é o fator regional. A gente que é aí da região de Governador Valadares. Não, por que... pra mim é uma questão regional, porque a gente que é daí vê sempre uma oportunidade de vida. (Entrevistado 04, cabo não retornado).

Aqui no Brasil, em Valadares especificamente, sempre teve aquela coisa de migrar pro Estados Unidos, então a gente já nascia vendo aquilo ali [...]. (Entrevistado 01, cabo retornado e demitido).

Podemos considerar que por viver em um território de forte tendência migratória, conforme explicado por Margollis (2013), Siqueira (2009) e Sales (1999), a presença de redes migratórias na Polícia Militar e a possibilidade de emigrar e retornar para o serviço militar foram fatores que estimularam a decisão de emigrar nesse período. Nesse sentido, problemas financeiros tinham como solução a emigração, como apontam os entrevistados 7, 3 e 8: 
E na época o recurso que o polícia normalmente sempre usa, parece que é uma cultura nossa, é deu um arrochozinho e a gente vai logo e pensa assim: "fazer um empréstimo", quer dizer, você resolve o problema na hora, e fica um outro a longo prazo pra poder desfazer dele, que é o tal da dívida. (Entrevistado 07, cabo retornado e reintegrado)

Melhorar financeiramente pra mim na época era tão simplesmente pagar o que eu devia, tendeu? Pagar o que eu devia e voltar. Na época eu tinha vários empréstimos [...]. (Entrevistado 03, soldado retornado e reintegrado)

Em 99, qualquer um que eu conhecia eu tava devendo... o meu cartão do banco ficava com agiota que eu tava devendo dinheiro pra ele. Aí, quando meu pagamento chegava, o agiota ia no banco e pegava a parte dele. (Entrevistado 06, sargento não retornado)

O fator econômico, como visto anteriormente, foi bastante presente na decisão dos militares entrevistados em migrar para os EUA, seguindo a linha da migração dos Valadarenses em geral, conforme explicam Siqueira (2009) e Margolis (1994 e 2013). É importante destacar que apesar da questão econômica ter sido forte incentivo para os militares que decidiram migrar, outros fatores também estiveram presentes, por exemplo, os provocados por situações pessoais, familiares, matrimoniais. Os EUA foram vistos por alguns militares não só como uma forma de ganhar dinheiro e resolver as questões de finanças, mas também como a oportunidade de uma mudança de vida em termos sociais, culturais. Esses são fatores que realçam em um território de emigração como é o caso de Governador Valadares

Quando Deleuze e Guattari (1997) explicam o processo de desterritorialização, que seria o movimento de fuga, e a reterritorialização como o movimento de construção do território, percebe-se em alguns dos militares que migraram o desejo de assumir uma nova vida; tal desejo vem acompanhado da desilusão com algo negativamente vivenciado na origem. Nos dizeres de Deleuze e Guattari (1997) é o desejo de deixar-se escapar de algo que precisa ser deixado e reconstruir uma nova identidade. Esse abandono e a reconstrução de uma nova identidade estiveram presentes de maneira bastante decisiva na migração de alguns militares, conforme pode ser visto nos relatos a seguir: 
Foi o meu emocional mesmo, foi o meu emocional, porque eu já estava vindo cinco anos que parecia que tava tudo dando errado,então eu queria cortar esse ciclo, eu precisava de cortar. Eu pensava: eu preciso dar uma basta nisso. (Entrevistadoo8, sargento retornado e reintegrado)

A motivação minha maior, a falta de perspectiva de ascensão na carreira que realmente estava bem restrito a vaga na polícia.(Entrevistado 04, cabo não retornado)

O fator emocional é uma variável constatada em algumas decisões. A necessidade de mudança, de reconstrução da vida, de ser uma pessoa nova, foi encontrada nos EUA como uma possibilidade para alguns. Assim, até mesmo a reconstrução da vida matrimonial foi um incentivo para um dos militares entrevistados, conforme relato a seguir:

A minha ideia de ir pros Estados Unidos surgiu depois que o meu exmarido foi embora, eu não tinha ideia de ir pro Estados Unidos (Entrevistado 01, cabo retornado e demitido)

A decisão de migrar perpassa por vários caminhos até se concretizar. Dos militares entrevistados, verificou-se que nenhum deles apresentou apenas um único motivo. Todos foram levados pelas diversas circunstâncias da vida. Alguns fatores incidiram em maior proporção, outros em menor, mas verifica-se um conjunto de fatores, contudo, um fator esteve presente em todos os entrevistados: o estímulo vindo das redes. Dos militares entrevistados, a maioria possuía parentes nos EUA e todos possuíam amigos que moravam lá há algum tempo. Conforme afirma Fusco (1998), a migração é como um processo criador das redes sociais porque desenvolve uma variedade de contatos entre locais de origem e destino. Verifica-se que os contatos são elementos facilitadores e estimuladores na decisão de migrar. Saber como, de onde partir, aonde chegar e quando migrar são informações que circulam na comunidade de modo geral e, sendo os militares da $8^{a}$ RPM participantes dessa comunidade, essas informações também lhes são acessíveis. A própria rede criada na região de Governador Valadares, explicada por vários autores como Margollis (1994), Fusco (1998), Fazito (2002) e Siqueira, Assis e Campos 
(2010), favoreceu o fenômeno da deserção na $8^{\text {a }}$ RPM com o objetivo de migrar para os EUA, tal como pode ser observado nas transcrições abaixo:

Essa pessoa que estava no Estados Unidos, que me ofereceu, ela que financiou pra mim. Aí eu não precisei de arrumar ninguém.(Entrevistado 03, soldado retornado e reintegrado)

Eu tinha vários amigos que moravam nos Estados Unidos e um amigo veio passear no Brasil, falou pra eu tentar o visto e se eu conseguisse o visto, ele ia me trazer pra cá e eu ia morar com ele mesmo [...]. (Entrevistado 06, sargento não retornado)

Os próprios militares que iam pra lá, dentro do batalhão eu consegui informação através deles de alguém que levava, tanto quando eu cheguei lá, eu cheguei no México, quem me recebeu lá foi outro polícia. (Entrevistado 14, soldado retornado e demitido)

Tomando por base a fala de Merton (1968), em análise ao estudo de The American Soldier, no qual explica a privação relativa por meio da insatisfação do indivíduo quando compara sua própria situação com a de outros do grupo, verifica-se que esse fator também incidiu na decisão de alguns militares em migrar para os EUA. O desejo de possuir o mesmo padrão de vida contribuiu para a tomada da decisão.

[...] e a gente via as pessoas que retornavam da América e retornavam assim, adquiria casa, comprava as coisas, era aquilo tudo que a gente queria.(Entrevistado 01, cabo retornado e demitido)

Outro importante quesito que contribuiu para o fenômeno da deserção com o fim de migrar foi a inexistência de uma norma administrativa que pudesse coibir sua prática. A norma criminal que punia o militar era de certa maneira branda em relação a impedir a consumação do crime de deserção. Prevista no art. 187 do Código Penal Militar, a pena é de seis meses a dois anos de detenção, sendo na maioria dos casos aplicada a pena mínima. O militar que desertava, ao se apresentar da deserção, era colocado na condição de preso e, posteriormente, cumpria seis meses de detenção, reintegrando-se 
normalmente nas fileiras da Corporação não sofrendo nenhuma sanção administrativa (BRASIL, 1969a).

O fato de poder reintegrar-se normalmente à Polícia Militar foi um incentivo para que vários militares praticassem a deserção no intuito de migrar para os EUA, conforme explica Lopes (2011) 82\% dos militares da $8^{a}$ RPM pesquisados em seu trabalho afirmaram que não teriam desertado caso a norma que passou a demitir os militares, estivesse em vigor.

Corroborando com esses dados, os militares entrevistados apontam a ausência de norma como um dos fatores que contribuíram para a prática da deserção com o objetivo de migrar para os EUA.

Aí na época eu sabia que eu poderia ir e voltar que eu iria ser penalizado, mas eu não iria perder minha profissão. (Entrevistado 03, soldado retornado e reintegrado)

[...] que era uma porta que a lei dava pro policial militar, poder desertar e retornar pra sua instituição sem correr o risco de perder seu emprego. (Entrevistado 07, cabo retornado e reintegrado)

Eu não retornaria. Pela instituição e pelas condições financeiras. Aí o senhor pode colocar mei a mei. Porque quanto mais hoje né, se cê for desertar cê tem um $\mathrm{PAD}^{2}$, igual eu vejo uns companheiro nosso. (Entrevistado 12, cabo retornado e reintegrado)

A ausência de uma norma administrativa que punisse com rigor o militar que cometesse a deserção foi fator decisivo para os militares migrarem para os EUA. A certeza da garantia do emprego no retorno permitia que esses militares desertassem para concretizar o intento de viajar, a longo prazo, para outro país.

A ausência da norma com a garantia do emprego na volta, remete automaticamente a outro fator que concedia estabilidade na decisão da viagem para os EUA: a ideia fixa do retorno. Emigrar sabendo que em algum momento retornaria para

\footnotetext{
${ }^{2}$ PAD - Processo Administrativo Disciplinar - Processo utilizado para análise da demissão do militar. MINAS GERAIS (2002)
} 
sua terra natal, sua gente e suas origens foi um contrapeso na hora da decisão. Conforme explica Sayad (2000), os migrantes partem com a ideia de voltar ao país de origem; o retorno está implícito ao próprio ato de migrar. No caso dos militares, tal intenção tornase evidente quando dos 14 entrevistados, todos afirmam que partiram com o propósito do retorno, mesmo aqueles que ainda não retornaram não só partiram com esse propósito, como ainda possuem o objetivo de um dia retornar, conforme pode ser observado nos relatos a seguir.

O meu plano era de ir, de dois anos e meio a três anos. Foi isso que eu... de dois anos e meio a três anos, foi isso que eu cumpri. (Entrevistado 14, soldado retornado e demitido)

Eu pensava, eu vou ficar três, quatro anos e depois volto. (Entrevistado 04, cabo não retornado)

A minha meta de retornar para o Brasil seria dez anos. Eu já fui com o planejamento de retornar com dez anos. (Entrevistado 08, sargento retornado e reintegrado)

Quando eu vim pro Estados Unidos eu vim com a intenção de ficar dois anos [...] Meu desejo de voltar, se o Pai [Deus] permitir, é final de 2015.(Entrevistado 09, sargento não retornado)

Segundo Sayad (2000), a perspectiva de que está se deslocando para a conquista de uma condição melhor de vida e que após algum tempo retornará para sua origem, faz com que o migrante se livre da culpa do abandono de sua terra e sua gente, pois emigrar é como uma maneira de desertar, uma forma de traição. Esse sentimento passa não somente pelo migrante, mas também pelo grupo ao qual ele pertence. No caso dos militares que desertaram para migrar para os EUA, esse sentimento possui dois pesos: o sentido da traição à pátria e o descumprimento do juramento ${ }^{3}$ feito ao ingressar na profissão de policial militar e a traição pelo abandono de sua terra e de sua gente. Por

${ }^{3}[. .$.$] prometo cumprir rigorosamente - as ordens das autoridades - a que estiver subordinado - respeitar os$ superiores hierárquicos - tratar com afeição os irmãos de armas - e com bondade os subordinados - e dedicar-me inteiramente ao serviço da pátria - cuja honra - integridade - e instituições - defenderei - com o sacrifício da própria vida. (BRASIL 2009) 
essa razão, talvez tenha sido, e ainda é, tão intensa e presente a ideia de retorno, contudo não há como dizer se a culpa pela ausência e pelo abandono foi um fator preponderante para essa "volta para casa". Assim como os fatores que influenciaram os militares na tomada da decisão de migrar são diversificados, os fatores que influenciaram no retorno também afetaram de maneira diferente cada um deles.

Vou ser sincera, eu voltei pra eu aposentar, pra eu ter meu emprego, minha vida tranquila, meu trabalho tranquilo, trabalho digno. Que eu pensava vou voltar, vou fazer curso de sargento, vou fazer faculdade, eu vou retomar no ponto que eu parei. Era isso que eu pensava. (Entrevistada 02, cabo retornado e demitido)"

Não, eu não voltei por causa da lei, eu voltei por causa do meu filho... eu voltei por causa do meu filho, porque se meu filho naquele momento falasse 'mãe, eu vou embora' eu não teria voltado. (Entrevistada 08, sargento retornado e reintegrado)

A ideia de retornar ao Brasil surgiu quando começou a surgir o rumor da lei, dessa lei ${ }^{4}$. O que me forçou mesmo, é... é... primeiro é a lei. (Entrevistado 07, cabo retornado e reintegrado)

Eu retornei mais por causa da PM, porque eu tinha esperança de poder retomar minha vida profissional. Mesmo porque eu já tinha também concretizado a questão de ter terminado a minha casa. [...] (Entrevistado 11 , sargento retornado e demitido)

Diferentes motivos incidiram na decisão do retorno: o advento da Lei que passou a permitir a demissão, punição prevista no Código de Ética e Disciplina dos Militares (CEDM), para aquele que desertava; o fator família; a ideia da retomada da carreira militar, entre outros, foram citados pelos militares entrevistados. Dessa maneira, percebe-se que apesar de condições semelhantes, os militares que migraram apresentam variações em seus motivos de retorno, tanto que alguns retornaram antes da vigência da Lei Complementar $n^{\circ} 95$ e foram reintegrados, outros retornaram após e foram demitidos

\footnotetext{
${ }^{4}$ Lei complementar $n^{\circ} 95$ de 17 de janeiro de 2007 que, entre outras alterações, classificou a deserção como transgressão contra a honra e o decoro da classe, passando a permitir a demissão do militar que cometesse tal crime. (MINAS GERAIS, 2007)
} 
e ainda há aqueles que por algum motivo não retornaram dos EUA, encontrando-se, ainda, na condição de desertores migrantes, somando um total de 39 militares pertencentes à $8^{\mathrm{a}}$ RPM, nesta condição. (MINAS GERAIS, 2002)

Segundo Sayad (2000), a ideia de retorno acontece concomitantemente com a decisão de migrar. Para alguns, essa ideia inicial, após a concretização da migração, passa a ser adiada consecutivamente e, sem que o migrante perceba, a migração que antes possuía caráter temporário vai se estabelecendo como quase que permanente, ou permanente em alguns casos. Ratificando essa afirmação, segue a fala de um dos militares entrevistados:

Então a gente vai com aquele pensamento assim: não, eu vou ficar dois anos e meio, três anos, mas quando na hora que assusta, passaram cinco, seis, sete anos. (Entrevistado 14, soldado retornado e demitido).

Assim, alguns dos militares que desertaram para migrar ainda permanecem, por motivos diferentes, no país de destino. Por meio das entrevistas realizadas com os militares não retornados, verifica-se que o retorno sempre está presente, mas a cada momento surge um motivo para que seja adiada essa decisão. Nos relatos a seguir, notam-se alguns desses fatores que fortalecem o não retorno.

Estava previsto deu voltar, após os dois anos de licença [...] Eu quase voltei pro Brasil, mas não tinha como. Eu já não voltava porque... tipo assim... eu já tinha minha própria empresa. [...] Só se a Polícia desse uma certeza que se eu voltasse eu não seria excluído. Aí a chance deu voltar de uma a dez, era oito. (Entrevistado 06, sargento não retornado)

Eu não retorno para o Brasil, primeiro meus filhos, a qualidade de vida que eu dou pro meus filhos, a qualidade de vida que eu proporciono pro meus dois filhos, eu tinha que ganhar no mínimo uns vinte mil reais por mês. Segundo, se eu voltar para o Brasil hoje, a policia militar não me aceita mais. (Entrevistado 04, cabo não retornado)

O que me segura aqui hoje é... eu tenho vontade de ir, mas se eu for eu vou ser mandado embora da Polícia. Eu tenho quarenta anos, como vou ficar com quarenta anos desempregado no Brasil? (Entrevistado 13, cabo não retornado) 
Observa-se que as condições econômicas no destino são determinantes para a permanência, contudo, a certeza de que no retorno serão demitidos pela Polícia Militar mostrou-se como um fator decisivo. Esses entrevistados possuem a esperança de que a demissão prevista pela Lei Complementar nº 95 para os casos do crime de deserção seja revogada em virtude de que, quando praticaram a deserção, a Lei citada não havia sido promulgada e não havia previsão da deserção como transgressão disciplinar, tampouco da punição com a pena de demissão. Essa esperança também se estende aos que retornaram e foram demitidos. Para defender essa ideia foi criada uma Associação ${ }^{5}$ com o objetivo de reivindicarem a volta ao serviço policial militar desses desertores. Assim esperam que seja, em algum momento, declarada a irretroatividade dessa norma impedindo que seja aplicada aos casos anteriores à sua vigência, de acordo com o princípio penal da retroatividade da Lei Penal que somente pode retroagir para alcançar fato anterior à sua vigência para beneficiar o réu. (GRECO, 2009).

A certeza de ser demitido se dá pelo fato de 52 (cinquenta e dois) militares, que retornaram após a vigência da norma, terem sido excluídos da Corporação.

O retorno ou não retorno está diretamente ligado à percepção do militar acerca do território, origem e destino. Conforme explica Sayad (2000, p. 14), "não se deixa uma terra impunemente, pois o tempo age sobre todos os seus pares". Assim, após a experiência migratória, o migrante, no caso do militar que desertou para migrar, conheceu outra realidade no país de destino e, adaptado, criou vínculos com aquele território, vínculos esses que influenciaram na decisão de retornar ou não à sua origem. Ao mesmo tempo, enfrenta o desafio de retornar para um mundo que já não é mais seu porto seguro. Não sabe o que vai encontrar, como readaptar-se no meio social, familiar e profissional, pois segundo Sayad (2000, p.14) “A imigração não ocorre sem deixar marcas". Ao deixar seu país, o migrante leva consigo toda carga de ressentimentos, tanto seu quanto dos que ficaram. Ao retornar, esses ressentimentos ainda persistem e alguns desses familiares e amigos nutrem, inconscientemente, sentimentos de inveja e de

\footnotetext{
${ }^{5}$ Associação de Desertores da Polícia Militar de Minas Gerais. Disponível no endereço eletrônico http://desertorespmmg.blogspot.com.br/ ou facebok

https://www.facebook.com/desertorespmmg.pec.g?fref=ts
} 
abandono, conforme explana Margollis (2013). A seguir, relatos de militares retratando a incerteza com o território de origem e o ressentimento de amigos.

Essa era uma das dificuldades que eu teria que enfrentar. Assim de [...] eu ia ter que começar uma amizade do zero, uma familiarização, sei lá como é que fala o nome... chamar alguém pra jogar uma partidinha de tênis que eu gosto. Teria que começar do zero. Eu não teria mais nenhum relacionamento com pessoas que eu pudesse conversar... (Entrevistado 06, sargento não retornado)

Os camarada fala pro cê, igual lá na justiça militar: "deu as costas pra polícia", cê ouvir isso é muito triste... (Entrevistado 10, cabo retornado e reintegrado)

Mas a gente sabia, que o pessoal comentava um com o outro [...] ah, esse daí já ganhou dinheiro lá, e ainda largou o Estado e ainda quer voltar. Tem que mandar embora mesmo! (Entrevistado 02, cabo retornado e demitido)

[...] eu via que existia um certa resistência por parte dos colegas com o desertor. Eles achava que o desertor não merecia tá na polícia, alguns, alguns, né, todos não, mas alguns. Eles não escondia aqueles sentimento deles de que o desertor tinha que ser desligado. (Entrevistado 07, cabo retornado e reintegrado)

Retomando o conceito de território trazido por Raffestin (1993) que abrange a relação social do indivíduo desenvolvida no espaço, verifica-se que a decisão de retornar é difícil para o emigrante, pois significa ganhos e perdas. No caso dos militares, retornar compreende a certeza de ser preso e assumir a condição de "criminoso" por haver desertado.

O que eu achei de dificuldade, é a maneira assim, como o Estado te faz sentir criminoso, isso aí mexeu muito comigo, e eu sofri mesmo, de verdade [...]. (Entrevistado 01, cabo retornado e demitido)

Dessa maneira, o militar que desertou para migrar percebe o território de destino, no caso os EUA, ainda como uma oportunidade e, ao mesmo tempo, vê o Brasil como 
uma incógnita e apesar de reportar à terra de origem como um aconchego onde pode encontrar (ou recuperar) o que deixou para trás, atribui a ela aspectos negativos como se, talvez, quisesse justificar seu longo período de ausência. Lourenço e Cunha (2012), ao explanar acerca da "síndrome do regresso", explicam que o processo de readaptação pode ser mais demorado que o de adaptação no país de destino. A seguir, trecho de uma entrevista de militar que desertou acerca das dificuldades do retorno.

A violência no Brasil hoje, eu tenho acompanhado por jornal, eu vejo a violência no Brasil, isso faz a gente ficar com medo de voltar. O custo de vida no Brasil não é fácil. (Entrevistado o9, sargento não retornado)

A experiência migratória muda a visão do mundo, do Brasil e, especificamente, da cidade de Governador Valadares. Segundo Sayad (2000) essa mudança resulta da ruptura constitutiva da emigração bem como da ausência subsequente, não consiste somente no envelhecimento físico, mas também é de ordem social. Dessa maneira, as mudanças advindas com a experiência migratória, consequentemente, alteram a percepção do militar quanto ao território (origem - destino). Valores, costumes, relações sociais vividas terminam por levar, ainda que inconscientemente, a uma comparação de um lugar a outro e criar o que Durkheim (2003) bem explica como juízo de valor.

Destarte, a percepção dos militares que desertaram para migrar para os EUA, após a experiência migratória, foi modificada e como o juízo de valor é algo personalíssimo, as percepções desses militares são diversificadas. Para alguns, estão acentuados os reflexos positivos, para outros os negativos, tanto no país de origem quanto no de destino, conforme se observa a seguir:

O amadurecimento veio de lá, pelo sofrimento. Pelo sofrimento e a maneira de ver a vida de outras maneiras né. Cê aprender a lidar com o povo, a ser educado. Porque antes a gente era... a nossa formação é uma formação bruta né, aquela formação bruta assim sem aquele conhecimento, hoje não. (Entrevistado 12, cabo retornado e reintegrado) 
É o comodismo, é achar que a rua ali tem que estar limpa porque a prefeitura, a prefeita, ela tem que colocar gari pra varrer. Não! A rua tem que estar limpa porque nós temos que ter consciência que nós não podemos jogar papel na rua. Antes não tinha essa visão não. (Entrevistado 08, sargento retornado e reintegrado)

A experiência migratória impactou a vida dos militares que desertaram e emigraram em várias dimensões. Não só na visão de mundo, de território, mas também na sua vida pessoal, no sentimento de pertencimento a um lugar, um grupo e o próprio sentimento de si mesmo. Conforme explica Siqueira (2009), nem todos os migrantes retornados conseguem sucesso em seu projeto migratório. Muitos voltam frustrados pelo fracasso do sonho não realizado, outros, mesmo obtendo sucesso não conseguem se adaptar e acabam por retornar para os EUA. Com os militares que desertaram para migrar não foi diferente, houve perdas e ganhos e, em alguns casos, mais perdas que ganhos.

Essa busca pelo bem-estar material, coloca, para o migrante, em contrapartida, perdas no plano sentimental e social. Algumas dessas perdas trouxeram ao militar que desertou a dor e o sofrimento de algo que se perdeu e, muitas vezes, de caráter irrecuperável; da frustração de algo não conquistado e, também, do constrangimento causado pelo retorno.

Porque eu consegui o material, mas eu perdi um contato com a minha família de três anos. Eu perdi, é uma lacuna. E é uma lacuna, uma coisa que vou te contar, parece que é irreparável. E eu não consigo libertar disso, eu convivo com isso todos os dias, por incrível que pareça. Porque a gente perde aquela coisa com a família, aquela união, aquela coisa de pai e filho, crescer junto. [choro] Então, teve sequelas também dentro dele (filho) e essa parte você não vai resgatar nunca, não tem nenhum bem material que pague isso. (Entrevistado 10, cabo retornado e reintegrado)

Para esse grupo de migrantes, especificamente, o impacto da experiência migratória é traumático, uma vez que não se trata apenas de um retorno às suas origens, mas também de se redimir do abandono da profissão que é tido como crime e, como tal, 
coloca o militar que migrou em condições análogas a de um criminoso potencial, pois a conduta de desertar, no que pese não ter socialmente uma conotação grave, para a Polícia Militar é tida como gravíssima e não só os comandantes, como também muitos dos subordinados e pares vêem o militar que desertou para migrar como um traidor que “virou as costas" para a Corporação A seguir, trechos das entrevistas que retratam essa situação. (MINAS GERAIS, 2007).

\begin{abstract}
Ah, é uma sensação horrível. Nossa, é vergonhoso! Eu tinha vergonha. Aí é que bateu o arrependimento. [...]Falei assim 'meu Deus, por que que eu fiz isso, né? Por que que eu voltei?' Se eu soubesse que o tratamento seria esse eu não teria voltado, sabe? Aí veio tudo. As pessoas passando perto da gente parecia que a gente tinha uma doença contagiosa. Ninguém olhava pra gente. (Entrevistado 08 , sargento retornado e reintegrado)
\end{abstract}

Então agora, dentro da policia, eu achei o mesmo preconceito porque eu fui mandado pra Resplendor e lá eu fui tachado como desertor- 'ó o desertor ali' - pelos colegas de serviço. (Entrevistado 14, soldado retornado e demitido)

[...] na época a gente ficava no xadrez, né. Fui preso e fiquei nove dias preso no xadrez. [...] Vergonha, né... vergonha. Pensa bem, seu pai é orgulhoso de vê você na rua trabalhando fardado, aí depois cê volta preso dentro do xadrez? É pesado. (Entrevistado 12, cabo retornado e reintegrado)

Neste sentido, o peso do retorno para o policial militar acentua-se, como já dito, pelo constrangimento de ser classificado como um criminoso. Essa situação agrava-se quando o próprio militar se percebe como tal, uma vez que contraria o seu senso de lealdada à profissão e a tudo aquilo que antes lhe era sagrado. Assim, a percepção do "ser policial" apresenta-se como algo sacerdotal. O amor quase que incondicional pela farda parece ser reforçado após a experiência migratória. Dos 14 militares entrevistados, reintegrados, demitidos e não retornados, todos relataram o sentimento de apego e veneração pela profissão de policial militar. Mesmo diante de algumas insatisfações com alguns ritos da Polícia Militar, os militares que foram reintegrados demonstram como 
ponto positivo o fato de terem retornado para a profissão, já os que foram demitidos trazem como maior prejuízo o fato de terem sido excluídos das fileiras da corporação. Os que não retornaram, colocam como maior anseio de retorno a possibilidade de serem reintegrados no serviço de policial militar. Verifica-se que o amor à profissão, transcrito no Regulamento de Continência das Forças Armadas, Brasil (2009), e adotado no âmbito da Polícia Militar, cuja fidelidade é confirmada com o sacrifício da própria vida, deixa o papel para se materializar na vivência de cada militar. É como se fosse um laço permanente que nem mesmo a demissão consegue desfazer.

Porque é um trem esquisito, parece que o sangue não muda, a gente entra dentro da polícia a gente pode fazer várias transfusão de sangue, que continua ter sangue de polícia. (Entrevistado 14, soldado retornado e demitido)

Pra te ser sincero, a única coisa que eu via de positivo na polícia era a beleza de ser policial militar. Quando eu fazia um $\mathrm{BO}^{6}$ eu achava aquilo uma coisa nobre. Eu achava nobre, muito nobre.

A polícia Militar é o meu sonho. Se hoje na polícia existisse uma lei que aceitasse os desertores, eu voltava para o Brasil. (Entrevistado 04, cabo não retornado)

Diante esses relatos podemos considerar que a experiência de migrar trouxe para os policiais militares que desertaram uma variedade de efeitos em suas percepções sobre o território, sobre Polícia Militar e sobre si mesmos. Levando-se em consideração que por mais semelhante que cada experiência tenha sido, nenhuma será igual à outra e, portanto, a percepção desses militares que migraram acerca da migração em si terá diferentes conotações. O que pode ter sido uma boa experiência para um, pode ter sido ruim para o outro.

\footnotetext{
${ }^{6}$ B.O. - Boletim de Ocorrência
} 
O que eu fui buscar, eu busquei e trouxe isso pra cá, mesmo ilegal. Eles te dão essa oportunidade lá. Aí eu fui, busquei isso aqui, e tô feliz aqui. (Entrevistado 02, cabo retornado e demitido)

Não! não valeu à pena ter migrado, não valeu, porque igual eu falei [...] por causa da minha filha, porque eu fui pra lá dar um futuro e tentar o melhor por ela. [...] Perdi o convívio, se eu estivesse aqui no Brasil, com certeza esse convívio não teria perdido. Então isso comigo foi a pior coisa que aconteceu. (Entrevistado 03, cabo retornado e reintegrado)

Não valeu à pena ter migrado. Pra mim não foi bom ...mesmo esse tempo deu ter migrado...mesmo eu tando fora do Brasil, meu corpo tá aqui, mas minha mente tá aí. Se eu tivesse ficado aí eu ia tá melhor do que aqui. (Entrevistado 13, cabo não retornado)

[...] no meu objetivo de dar educação pros meus filhos, valeu à pena sim, mas quando eu parto pro laço de afetividade com meus filhos, eu acho que não valeu à pena ter migrado. $O$ que eu perdi... isso de brincar com eles assim... éééé... isso não volta mais, agora só se for com meus netos. (Entrevistado 06, sargento não retornado)

Os relatos permitem considerar que dos militares que desertaram para migrar, nenhum deles ficou inerte em meio ao fenômeno, pois transformações fizeram parte desse processo. Tomando por base os dizeres de Sayad (2000), constata-se que não há como se inserir nesse sistema migratório sem que haja rupturas e essas rupturas criam cicatrizes, buracos e abrem e fecham caminhos.

O processo de fuga, citado por Deleuze e Guattarri (1997) está presente nas experiências narradas pelos militares que desertaram para migrar, pois todo o processo dessa mudança exigiu que ele desterritorializassem, inclusive da condição de policiais militares, para reterritorializarem-se em outra realidade, onde a farda foi deixada para trás, juntamente com todos os valores normativos e morais que a acompanham, para que pudessem se estabelecer numa terra estranha onde o objetivo principal era buscar uma “melhor condição de vida" para si e para os seus.

A partir das análises, com base nos relatos e do referencial teórico, verifica-se que, de maneiras diferentes, após a experiência migratória, o policial militar que desertou foi impactado pelo processo sob o qual se inseriu, ou seja, a migração e todas as nuances que envolvem esse instigante processo de movimento de um território para outro. 


\section{Conclusão}

A cidade de Governador Valadares é um território de cultura emigratória com fluxo significativo para os EUA e Europa (SIQUEIRA, 2009, MARGOLIS, 2013). É nesse território que ocorre um fenômeno intrigante no contexto das migrações brasileiras: a deserção dos militares da Oitava Região da Polícia Militar. Com a finalidade de emigrar, criou-se um grupo de policiais militares sob o qual centraliza as análises deste artigo, cujo foco principal é compreender os impactos da experiência migratória na percepção do território pelo militar desertor que foi reintegrado após o retorno; pelo que foi demitido e pelo que, ainda, permanece no país de destino.

Os militares migrantes desertores são em sua maioria homens, jovens entre 26 e 35 anos, da classe de soldados e cabos e possuíam estabilidade na corporação quando migraram.

Conforme analisado, vários são os fatores motivadores para migrar, dentre eles destacamos a cultura da emigração presente no território, as redes, a privação relativa e a ausência da norma. Ressaltamos que a ausência da norma (lei complementar $n^{\circ}$ 95) foi um fator de maior peso. Ao emigrar, além do pecado da ausência explanado por Sayad (1998), o militar esta deixando de honrar o juramento feito ao assumir sua profissão de militar.

Após análise dos dados, obtidos por meio de entrevistas, verificou-se que alguns fatores foram proeminentes na decisão de migrar para os EUA, dos quais destacam-se o econômico, a rede, a privação relativa, motivos pessoais e a possibilidade do retorno para o país de origem; mas a ausência de norma apresenta-se, no caso do grupo estudado, como um dos principais estímulos.

Os militares foram unânimes em afirmar que caso a norma que passou a permitir a demissão do militar que comete a deserção estivesse vigorando quando decidiram migrar para os EUA, não o teriam feito. Esse é um fator relevante demonstrado tanto nos relatos quanto no fato de que após a vigência da Lei que passou a permitir a demissão dos que cometiam a deserção, apenas três casos ocorreram na $8^{\mathrm{a}}$ RPM. 
Ao analisarmos a ausência da norma como estímulo para o cometimento da deserção seguido da migração para os EUA, verifica-se o apreço à profissão. Demonstração disso são as iniciativas dos militares demitidos e dos ainda não retornados para a revisão da norma, pois, no entendimento deles, não poderia demitir aqueles que migraram cientes de que poderiam retornar para a carreira militar. Os militares desertores demitidos da Corporação criaram uma associação que busca na justiça a declaração de inconstitucionalidade da Lei complementar 95 que proporciona a demissão do militar desertor para os casos ocorridos antes de sua vigência.

Os militares que migraram, retornaram e foram reintegrados na Polícia Militar, em unanimidade, afirmaram que retornaram em virtude da norma já mencionada que havia sido promulgada em 17 de janeiro de 2007 e entraria em vigor 3 meses depois (período de vacância), ou seja, em 17 de abril de 2007. Nesse período de três meses, os militares que desertaram poderiam retornar e sofrer apenas as sanções criminais e não seriam demitidos da Corporação. Após o período de vacância da norma, aos que retornassem, a Lei passou a permitir a submissão ao processo disciplinar com a consequente demissão, como, de fato, ocorreu.

Já os militares que retornaram e foram demitidos apresentaram motivos diversos para o retorno. O fato de terem voltado após a entrada em vigor da Lei, já descarta tal lei como fator motivador para a volta ao Brasil, ao contrário dos que foram reintegrados, alimentavam a crença de que a Lei complementar não poderia demitir o militar que desertasse. Percebe-se que esse grupo, diferente do grupo que fora reintegrado na Corporação, afirma que, ao retornar, o fizeram por terem cumprido o objetivo de sua ida para os EUA; essa fala é comum ao grupo. Saudades do Brasil (incluindo familiares e amigos) é outro estímulo citado por eles em seus relatos. Fica evidente a ideia de pertencimento ao Brasil e enfatizam os EUA apenas como um país de passagem; destacam o sentimento de estranhamento em relação ao destino.

De modo geral, tanto os militares retornados reintegrados quanto os demitidos apresentaram como motivação comum para o retorno, a expectativa de retornarem para a carreira militar, mesmo, no caso dos demitidos, cientes da vigência da norma que 
permitiu a demissão do que desertava, alimentavam a esperança de permanecer na Corporação.

Diferentemente, os não retornados, apresentaram como fator preponderante a certeza de que no retorno serão demitidos da corporação, pois tiveram notícias da demissão dos que retornaram após a vigência da norma demissionária, contudo guardam a esperança da mudança da lei, isto é, esperam que seja declarada a irretroatividade da norma e, assim, não só deixe de demitir, mas também reintegre os que já foram demitidos no mesmo contexto.

Outro fator que foi evidenciado pelos não retornados foi a estabilidade financeira adquirida nos EUA. Dos quatro entrevistados três possuem o próprio negócio e o que trabalha como empregado afirma está em situação financeira estabilizada. Soma-se a essa questão o incentivo dos familiares pela permanência dos militares nos EUA, uma vez que estão estabilizados financeiramente naquela nação.

A primeira constatação do impacto na percepção do militar emigrante é na cultura diferenciada dos países de destino e origem. Os entrevistados são enfáticos em afirmar que o tempo de permanência no país de destino mudou seu modo de pensar. A questão da disciplina às normas sociais, o cumprimento rigoroso de condutas éticas e do bom convívio social é citado por todos os entrevistados, e vai desde jogar um simples pedaço de papel no lixo até ao estrito cumprimento das regras de trânsito. Comparam o Brasil de forma negativa nesse quesito.

Percebe-se que a visão de mundo também foi modificada. Ao conhecer pessoas de outras nacionalidades, não só americanos, os entrevistados ampliaram suas relações sociais e agenciamentos. Alguns afirmam ter aprendido a falar o inglês, outros o espanhol e há quem admite ter aprendido as duas línguas. O contato com estrangeiros foi um impacto positivo permitindo a eles perceber um mundo além de suas experiências antes de emigrar.

A ideia de se estabelecer naquele país, trabalhar, ganhar dinheiro em pouco tempo para realizar seus objetivos e retornar, os atraiu e alimentou a crença de que a solução de seus problemas estaria na emigração. Dos entrevistados dez militares dizem ter valido à 
pena migrar, mesmo os que foram demitidos da Polícia Militar, três são enfáticos em afirmar que foi positiva a experiência.

Ressalta-se que mesmo havendo um saldo final positivo, os entrevistados destacam que os aspectos negativos também estão presentes, dentre eles a distância dos familiares e o tempo de ausência que não há como recuperar.

Com relação à profissão de policial militar, verifica-se que a visão desses migrantes, a forma de perceber a Polícia Militar, não foi modificada. No que pese ser citado pelos entrevistados, algumas insatisfações com certos ritos da Instituição. Dos 14 entrevistados, 13 percebiam, antes de migrar, a Polícia Militar como algo sacerdotal e expressaram a "paixão pela farda". O termo por eles utilizado é que a "a polícia está no sangue." Após a experiência migratória, a percepção de ser e estar na polícia não mudou essa concepção, ao contrário, intensificou esse apreço, tanto que do grupo de militares demitidos, todos afirmam se sentirem ainda policiais e alimentam a ideia de que ainda vão retornar para a corporação. Para os demitidos a maior perda foi a da profissão.

Verifica-se que os militares que desertaram não percebiam o ato de migrar, ou seja, ausentar-se por um tempo como um crime. Acreditavam que retornariam e seriam normalmente reintegrados à corporação. Após o retorno, com a prisão em cela, a percepção desses retornados acerca do ato de desertar tomou outra conotação, pois o constrangimento de se sentir preso e criminalmente responsabilizado diante dos colegas de fardas e familiares trouxe a consciência de que estavam sendo vistos e tratados como criminosos. Nos relatos, essa sensação e sentimento são evidenciados com emoção, carregados de revolta, arrependimento e constrangimento de se encontrarem na condição de presos.

Nesse ato de desertar, eles acreditam que podem se redimir no retorno cumprindo a punição definida pela lei. Na punição haveria a purgação do pecado cometido contra a corporação e contra a pátria, ou seja, a deserção. Passando pelo constrangimento da prisão, havia a garantia de reintegração. Com a vigência da lei complementar $n^{\circ} 95$, essa possibilidade cessa e, consequentemente, reduz o número de militares que desertam para emigrar. 
Evidentemente não se pode deixar de levar em consideração a crise que se abate sobre a economia dos EUA e que reduz significativamente o fluxo migratório de modo geral, contudo os relatos nos permitem considerar que a norma tem um peso significativo na decisão de emigrar.

Retomando a questão central desse estudo, "qual é o impacto da experiência migratória na percepção do território pelo policial militar desertor que foi reintegrado após o retorno; pelo que foi demitido e pelo que, ainda, permanece no país de destino?". Pode se concluir que os militares da $8^{\mathrm{a}}$ RPM que desertaram para migrar para os EUA tiveram suas vidas impactadas pela experiência migratória. Modificações não só em suas vidas, mas também de familiares, ocorreram ao longo dessa trajetória. O processo de desterritorialização e territorialização estão presentes.

Em um território marcado pela emigração, como é o caso da região de abrangência da $8^{a}$ RPM, migrar é uma alternativa viável. Os militares não foram imunes a essa cultura, contudo existiam implicações que os diferenciavam dos outros habitantes, como seu compromisso legal com a corporação. Se numa perspectiva social, conforme explica Sayad (2000), emigrar é abandonar o seu território e a sua gente, para o policial militar é um crime regido pela lei. A convivência com esse território de emigração e a possibilidade de retornar para a corporação após a experiência migratória tornou a deserção como uma falha, percebida pelos desertores, não muito grave e possível de ser redimida.

A não existência da lei que punia com a demissão levou muitos a emigrar, considerando que no retorno, esse aspecto legal, do seu pecado poderia ser redimido e assim retornariam para a corporação e para sua profissão. Com a vigência da lei a possibilidade de remissão é fechada. Nessa perspectiva, alguns retornaram dentro do prazo estipulado pela lei, outros permaneceram retornando apenas depois do prazo, na expectativa de conseguirem ser readmitidos. Outros não retornaram.

Essa decisão pesou de forma diferente para cada um. Dentre os relatos dos que não retornaram, a situação econômica de ganhos maiores no destino do que no Brasil, foi determinante. Para os que retornaram a tempo de cumprir a punição e serem 
readmitidos, é evidente que o custo-benefício da perda da profissão foi o fator determinante. Para os que retornaram depois do prazo, com a esperança de serem readmitidos, o fizeram com o indicativo que esse era um grande risco, pois outros já haviam sido demitidos e o custo do retorno foi marcado também por outros fatores, como relataram (saudades da família, crise na economia americana, etc.).

Para o grupo estudado, a demissão em função da deserção é um pecado que deixa uma cicatriz que mesmo os que foram readmitidos, consideram permanente em suas vidas. Essa é considerada a maior perda.

Esse artigo demonstra como a cultura da emigração marca não só o território, mas as vidas daqueles que nele vivem e são transpassados direta ou indiretamente pelo fenômeno.

\section{Referências}

BRASIL, Senado Federal. Decreto-Lei 1.001, de 21.10.1969. Brasília: Senado Federal, Centro Gráfico, 1969 a. Contém o Código Penal Militar

. Ministério de Estado da Defesa. Portaria Normativa 660/MD. Aprova o regulamento de continências, honras, sinais de respeito e cerimonial militar das forças armadas. Brasília: Ministério de Estado da Defesa, 2009

DE HAAS, H. Migration and development: a theoretical perspective. IMR, v. 44, n. 1, p. 227-264, Local: Spring, 2010.

DELEUZE, G. e GUATTARI,F. Mil Platôs: capitalismo e esquizofrenia. Rio de Janeiro: Editora 34. 1997. Vol. 5

DURKHEIM, É.; RODRIGUES, J. A. (Orgs.). Sociologia. 9. ed. São Paulo: Afiliada, 2003.

FAZITO, D. Análise das redes sociais (ARS) e migração: mito e realidade. In:, 13, Caxambu 2002. Anais eletrônicos. Caxambu Associação Brasileira de Estudos Populacionais, 2002. Disponível em http://www.abep.nepo.unicamp.br/docs/anais/pdf/2002/GT_MIG_ST1_Fazito_texto.pdf

FERREIRA, A. B. H. Mini Aurélio: minidicionário da língua portuguesa.6. ed. Curitiba: Positivo 2004. 
FUSCO, W. Redes sociais na migração internacional: o caso de Governador Valadares, Campinas: IFCH -UNICAMP, 1998.

LOPES, L. B. Análise do art. 240-A do Estatuto dos Militares do Estado de Minas Gerais Face à Deserção na $8^{\text {a }}$ Região da Polícia Militar de Minas Gerais: 2011, 98 p. Monografia (especialização) - Centro de Pesquisa e Pós-Graduação - Academia de Polícia Militar de Minas Gerais. Curso de Especialização em Segurança Pública, Belo Horizonte, 2011.

LOURENÇO, A.; CUNHA, J. De volta ao país, brasileiros sofrem "síndrome do regresso". Folha de São Paulo, 06 de março de 2012. Disponível em:

<http://www1.folha.uol.com.br/equilibrioesaude/2012/03/1055239-de-volta-ao-paisbrasileiros-sofrem-sindrome-do-regresso.shtml>. Acesso em: 13 jan. 2015.

MARGOLIS, M. L. Good BYE, Brasil: emigrantes brasileiros no mundo. Tradução Aurora M. S. Neiva, São Paulo: Contexto, 2013.

. Little Brazil, imigrantes brasileiros em Nova York. Campinas: Papirus 1994.

MASSEY, D. S. et al. Theories of international migration: a review and appraisal. Source: population and development review. v. 19, n. 3, p. 431-466, Sep. 1993.

MERTON, R. K. Sociologia: teoria e estrutura. São Paulo: Mestre Jou 1968.

MINAS GERAIS. Lei Estadual Complementar 95 de 17 de janeiro de 2007: altera a lei 5.301 de 16 de outubro de 1969. Belo Horizonte: Governo do Estado, 2007

. Lei Estadual 5.301de 16 de outubro de 1969. Belo Horizonte: Governo do Estado, 1969. Contém O Estatuto dos Militares de Minas Gerais.

.Lei Estadual 14310 de 21 de junho de 2002. Belo Horizonte: Governo do Estado, 2002. Contém o Código de Ética e Disciplina da Polícia Militar.

MINAS GERAIS, Resolução № 4220 de 28 de junho de 2012 - CG. Belo Horizonte: Polícia Militar, 2012. Cria o manual de processos e procedimentos administrativos das instituições militares de Minas Gerais (MAPPA).

PECEQUILO, C. S. As relações Brasil-Estados Unidos. Belo Horizonte: Fino Traço, 2012.

RAFFESTIN, C. Por uma geografia do poder. Tradução de Marília Cecíla França. São Paulo: Ática, 1993.

SALES, Teresa. Brasileiros longe de casa. São Paulo: Cortez, 1999. 
SAYAD, A. A imigração ou os paradoxos da alteridade. São Paulo: Universidade de São Paulo, 1998.

, O retorno segundo Abdelmalek Sayad. Travessia, São Paulo, v. Especial, p. 3-33, jan. 2000.

SIQUEIRA, S. Sonhos, sucessos e frustrações na emigração de retorno. Belo Horizonte, MG: Argvmentvm, 2009.

SIQUEIRA, S.; ASSIS, G. O.; CAMPOS, E. C. As redes sociais e a configuração do primeiro fluxo emigratório brasileiro. Análise comparativa entre Criciúma e Governador Valadares. In: ABREU, J. L. N.; ESPINDOLOAL, H. S. S. (Orgs). Território sociedade e modernidade. Governador Valadares: Univale, 2010.

SKELDON, R. Migration transitions revisited: their continued relevance for the development of migration theory. Population, Space and place v. 18, n. 1, p. 154-166, 2012. 